\title{
Entrepreneurial Intentions of Students (Based on the Example of a Chosen University)
}

\begin{abstract}
Joanna Gajda*
In today's knowledge-based economy, it is particularly important to take measures to increase innovation and entrepreneurship. Entrepreneurial society becomes the foundation for building the competitiveness of the Polish economy. In this context, it is important to shape an entrepreneurial society that is characterized by active participation in the development of entrepreneurial initiatives. Being entrepreneurial means willingness to adopt the attitude expressed through a creative approach to economic reality. In the process of preparation of human resources for entrepreneurial activity, the key role is attributed to education, which boils down to raising the awareness that starting and running a business is a path of career development.

The article is divided into two parts. The first, theoretical, part contains reflections on selected factors affecting the development of entrepreneurial intention, which is the beginning of the process of individual entrepreneurship. In the second part, the author briefly presents the results of pilot studies carried out to analyze the intentions of enterprising students of the Technical University of Czestochowa, in relation to issues such as: the perception of entrepreneurship and conditions for the initiation and conduct of business, and assessment of entrepreneurial potential.
\end{abstract}

Keywords: entrepreneurial intentions, entrepreneurship, perception of entrepreneurial potential, educational system, entrepreneurial attitudes.

Submitted: 30.05.2016 | Accepted: 18.08.2016

\section{Intencje przedsiębiorcze młodzieży akademickiej (na przykładzie wybranej uczelni)}

W obecnych realiach gospodarki opartej na wiedzy szczególnego znaczenia nabiera podejmowanie działań na rzecz wzrostu innowacyjności i przedsiębiorczości. Społeczeństwo przedsiębiorcze staje się fundamentem budowania konkurencyjności polskiej gospodarki. $W$ tym kontekście ważne jest ksztattowanie społeczeństwa przedsiębiorczego, którego wyróżnikiem jest aktywny udziat znacznej jego części $w$ rozwoju inicjatyw przedsiębiorczych. Bycie przedsiębiorczym oznacza chęć przyjęcia postawy wyrażajacej się kreatywnym podejściem do rzeczywistości gospodarczej. W procesie przygotowania kadr do przedsiębiorczej działalności kluczowa role przypisuje się edukacji, która sprowadza się do ksztattowania świadomości, że uruchomienie i prowadzenie wtasnej działalności jest ścieżka rozwoju kariery zawodowej.

Artykut składa się z dwóch części. Pierwsza część wpisuje się w nurt rozważań nad wybranymi czynnikami mającymi wptyw na ksztattowanie się intencji przedsiębiorczych od której zaczyna się proces przedsiębiorczości indywidualnej. W drugiej części autorka skrótowo prezentuje

Joanna Gajda - PhD, Faculty of Management, Czestochowa University of Technology

Mailing address: Faculty of Management, Czestochowa University of Technology, Bialska St. 59/3, 42-200 Częstochowa, e-mail: joannagajda@vp.pl. Ministry of Science
and Higher Education Republic of Poland
The creation of the English-language version of these publications is financed in the framework of contract No. 768/P-DUN/2016 by the Ministry of Science and Higher Education committed to activities aimed at the promotion of education. 
wyniki badań pilotażowych zrealizowanych $w$ celu przeanalizowania intencji przedsiębiorczych studentów Politechniki Częstochowskiej, w odniesieniu do takich kwestii jak: percepcja przedsiębiorczości oraz warunków do zainicjowania i prowadzenia własnej działalności gospodarczej, ocena wtasnego potencjatu przedsiębiorczego.

Słowa kluczowe: intencje przedsiębiorcze, przedsiębiorczość, percepcja potencjału przedsiębiorczego, system edukacji, postawy przedsiębiorcze.

Nadesłany: 30.05.2016 | Zaakceptowany do druku: 18.08.2016

JEL: L26

\section{Introduction}

With the development of economy based on knowledge and evolution of information society there are challenges in the form of reconstruction of educational objectives and related content, learning outcomes aimed at improving the quality of education and learning at all levels of education, and adaptation to the socioeconomic changes (Kilar and Rachwał, 2014, pp. 112 113). Given these priorities, it is necessary to shape entrepreneurial attitudes of young people, especially in the context of activities carried out at universities and lifelong learning. This is of particular significance in times of increasing turbulence and complexity of the environment in which organizations operate. Uncertainty arising from the variability of environment is reflected in limited possibilities of finding a job on local and regional markets, which nowadays are characterized by high levels of unemployment, especially among young people (Kirchschlaeger, 2014, p. 238). Although this situation is not optimistic, young people often see chances for the realization of their own needs and opportunities for self-employment.

For this reason, the aim of entrepreneurship education is to prepare young people to take economic initiatives with the support of skills associated with establishing and running their own businesses, allowing them to succeed.

The article briefly presents the results of pilot studies carried out in order to analyze entrepreneurial intentions of students in relation to issues such as: the perception of entrepreneurship and conditions for the initiation and conduct of business activity, and assessment of entrepreneurial potential. The research was conducted in the first quarter of 2016 among 158 students of the fourth semester of full-time undergraduate degree, majoring in Finance and Accounting at the Faculty of Management of Czestochowa University of Technology. Students participating in classes of human resource management in financial institutions were asked to complete a questionnaire designed to determine their entrepreneurial intentions associated with a tendency to start their own business. The research on entrepreneurial intentions of students is quantitative and was carried out with the use of an audit questionnaire.

The author is aware of the restrictions of the research in this article, since it was conducted on a small group of respondents, and the results are not universal. They are only a starting point for further and broader research on entrepreneurial intentions among a representative sample. To obtain valuable results, it will be necessary to expand research tools and include students of other universities from other cities.

\section{The Impact of Education on the Development of Entrepreneurial Attitudes of Students}

Basing on a review of research on academic entrepreneurship, it can be assumed that universities are areas promoting activities aimed at development of entrepreneurial attitudes among students. In this context, the cooperation between education and business is particularly important, and it is reflected in participation in creation of interaction mechanisms between elements of this system. Therefore, the question arises - what is the cooperation between education and business?

One of the proposed forms of cooperation is the formation of business incubators to encourage entrepreneurship, both 
in students and academic staff of universities (Tunkkari-Eskelinen and Viitasaari, 2015 , p. 729). Meetings organized as part of cooperation between entrepreneurs and academic community interested in entrepreneurship are important as well. All participants taking part in innovative projects benefit from such cooperation (Myjak, 2014, p. 176)

An important task of universities is to create conditions to establish active cooperation with industry in many areas: research, commercialization of technology, development of education process through practice (organizing apprenticeships, student internships, conducting some courses for apprentices of enterprises). These actions are an example of real participation of educational institutions in shaping the competitiveness of the region. Universities, by focusing on teaching and implementation of research, have influence on entrepreneurial behavior of students, giving them the opportunity for independent and autonomous activities related to running their own business (Buchta and Jakubiak, 2014, p. 170)

It turns out that activities aimed at promoting entrepreneurship education and adapted to the field of study at the academic level are necessary on the part of university. There is also a need to start activities for substantive and methodological support for teachers leading classes in the subject of "entrepreneurship" (RichertKaźmierska, 2011). There is also a need to include entrepreneurs in the teaching process of universities. It would be good if, as part of cooperation, entrepreneurs gave occasional lectures.

An optimal situation would be if the alternation of roles in management and education occurred. The experience of business representatives involved in the teaching process shows that interest in issues concerning the development of entrepreneurship among young people increases when acquired theoretical knowledge can be verified in practice. A good way to gain initial experience in business is to encourage students to participate in student internships during which they will be able to develop organizational skills (Deszczyński, 2007, p. 87).

The main educational task of the university is to provide students with knowledge of how to develop entrepreneurial attitudes and characteristics. A major problem in teaching entrepreneurship at the university is the need for solutions for the development of creative potential of students. Selection and use of activating teaching methods, as opposed to working with a textbook, can help to activate entrepreneurial behavior in students.

To ensure a balance between theoretical knowledge and practical application, the following should appear in the learning process: interactive and pragmatic methods, active and independent learning, teaching focused on action, group work, learning through projects, learning through experience, methods of self-development and self-esteem. Such transfer of information is essential to keep students' motivation at a high and satisfactory level (see: Przedsiębiorczość w szkolnictwie wyższym...).

To develop the qualities and entrepreneurial attitudes in students, the teacher should exert psychological influence. The awakening of their entrepreneurial spirit leads to increased opportunities to use their talents and abilities. It is important to use theoretical knowledge as well, because it provides a basis for knowledge of economic mechanisms, business conditions, problemsolving and decision-making within the adopted business activity, and establishing relationships with other people (Bagheri and Pihie, 2014, p. 146). To be able to correctly use theoretical knowledge, students should also develop skills in (Choinkowska, 2012):

- the creation of scenarios for the future,

- setting goals and striving to achieve them,

- identifying business opportunities,

- making social contacts,

- using their talent,

- creative thinking,

- starting a new venture.

The methods and the quality of education unquestionably affect the intellectual level of students. As part of development of entrepreneurial behavior of young people, which takes place with the substantive support from academic staff, projects of an entrepreneurial character should be implemented and they should engage students to participate in group activities. Furthermore, young people declaring a desire to start their own business should have a substantive support from the university at the initial stage of their business. A useful form 
of the classes may be seminars where it is possible to gain experience by engaging in the process of research in organizations (Myjak, 2014, p. 177).

The process of education should develop skills which give a solid preparation for the role of an entrepreneur at the end of education at the university. In this context, emphasis should be put on increasing the entrepreneurial awareness among all students from departments of economics, management and others. Therefore, universities should bring forward proposals of a wide range of subjects (Butler and Mador, 2015). According to the recommendations of the Bologna Process, teaching should be oriented towards the development of essential entrepreneurial skills necessary to manage a business, not only at the stage of starting a business but also in the growth phase. Knowledge alone is not a sufficient basis for developing entrepreneurial attitudes of young people and influencing business plans. An efficiently designed curriculum should include the experience and capabilities closely associated with being an entrepreneur (OECD, 2005, p. 96).

Among experts, there is a view that the objectives, content and teaching methods should be adapted to the level of education. Students enrolled at the undergraduate level should participate in activities that help in improving the way of thinking and developing interest related to establishing their own business. In the case of students of the second degree and doctoral students, it is important to equip them with practical tools necessary for learning specific skills and to support them in development of business ideas (see: Przedsiębiorczość w szkolnictwie wyższym...).

\section{Determinants of Shaping Entrepreneurial Intentions}

A prerequisite for the existence of an entrepreneurial process is a positive perception of entrepreneurship, which may have a significant impact on the increase in the level of entrepreneurial intentions (Brenes and Haar, 2012, p. 78). Entrepreneurial intentions direct human attention to the achievement of chosen objectives associated with initiating a business.

Starting a business is a long-term process which involves the need to make complex decisions, and therefore cannot be seen in the context of a single choice leading to the company's entry into the market. The entrepreneurial process begins with the first entrepreneurial intentions that appear in human mind, that is when one considers starting a business venture, and ends with the start of a business activity (Gawel and Pietrzykowski, 2015, p. 43).

Entrepreneurial intention is a term widely analyzed in the literature on entrepreneurship. It is worth referring to one of the most common definitions of this concept proposed by the eminent researcher N. Krueger. That author defines entrepreneurial intentions as a conviction of a man to take up an economic activity and conscious planning of this project in the longterm perspective (Krueger, 1993, pp. 5-21).

Models based on intentions are used in the studies on entrepreneurship conducted on the basis of management science, although they are derived from social psychology. On their basis, there is a possibility of making predictions on future behavior, which is gaining importance from the point of view of management and entities taking responsibility for developing entrepreneurship support systems and is a very important element falling within this scope, namely entrepreneurship education, whose main task comes down to the formation of desired entrepreneurial attitudes (Wach, 2015, p. 26).

Most approaches that include the issue of development of entrepreneurial intentions are supported by the theory of planned behavior, the model of entrepreneurial event and the model of implementing entrepreneurial ideas (entrepreneurial cognition). Ajzen's theory of planned behavior assumed that human activity is dependent on three subjective factors (Kocoglu and Hassan, 2013, pp. 243-252):

- attitude associated with a positive or negative assessment of the object,

- subjective standards, namely the perception of pressure from the nearest social environment in the context of the analyzed behavior,

- control over the behavior, which manifests in the perception of one's own capabilities in the implementation of specific behavior.

These factors affect the intention connected with starting a company that precedes the behavior. Application of this 
theory is justified when it comes to behavior associated with starting a business, and the knowledge and skills are necessary for implementation of this project. It should be noted that all decisions regarding the initiation of an action should be made thoughtfully (Bednarski, Gryzik, Matusiak, Mazewska and Stawiasz, 2009, p. 60).

Another idea worthy of wider attention and analysis is the model proposed by $\mathrm{A}$. Shapero referred to as the model of entrepreneurial event that allows for identifying the determinants shaping entrepreneurial intentions. According to this model, the entrepreneurial intention is a result of three factors, namely: desire, feasibility and willingness to seize an entrepreneurial opportunity (Elfving, Brännback and Carsrud, 2009, p. 24). Studies on this issue indicate that one of important factors determining entrepreneurial intentions is internal locus of control. This phenomenon is not regarded as a feature contributing to the company founding but as behavior subjected to change. It is a result of the entrepreneur's growing control over the environment (Zbierowski, 2014, p. 54), which, in regard to intentions, can be defined as the entrepreneur's perceived self-control (Uygun and Kasimoglu, 2013, p. 24).

The model created by A. Shapero assumes that the intention is a condition that precedes entrepreneurial behavior, if only there is such a possibility (Krueger, 2002 , p. 232). The appearance of this behavior depends on the perception and evaluation of one's own desires and pursuit of one's plans. These factors are dependent on the influence from outside. Another determinant which shapes human intentions is the ability to act. Activation of entrepreneurship is influenced by events understood as stimulants to initiate a business. Such incentives include: finishing education, encouragement to start a business from another person or loss of a job (Kurczewska, 2010).

Research on the source of entrepreneurial intentions suggests that entrepreneurial intentions are influenced by demographic factors and attitudes resulting from life experience. In the light of psychological model of determinants of entrepreneurial intentions proposed by P. Davidsson, one of the areas which are important in the development of an entrepreneurial behavior is personal background, with gender being its main element (Tomski, 2015, p. 83). Literature studies confirm that in relation to the theory of P. Davidsson, a list of variables that contribute to explaining the intent and human behavior with entrepreneurial characteristics was developed. Among other factors of this model are: age, desire for autonomy and achievement, professional experience, the ability to see and react to changes in the environment, and cultural norms (Zbierowski, 2014, p. 54).

Researchers of the issues relating to entrepreneurial intentions attempted to develop a list of characteristics of an entrepreneurial person in the form of entrepreneurial profile. Despite the lack of conclusive evidence that the structure of entrepreneurial human personality is a specific system of psychological traits responsible for decision-making and entrepreneurial activities, there is no doubt, however, that the success in business is linked with certain predispositions (Canós-Darós and Santandreu-Mascarell, 2011, p. 230). An example of an entrepreneurial profile presenting a set of characteristics which determine the success in running a business is a profile proposed by D. Kuratko and $\mathrm{R}$. Hodgetts. This profile includes a set of the following attributes: commitment, determination, perseverance, a strong need for achievement, taking calculated risks, searching for opportunities, honesty, creativity and innovation, seeking feedback (Kraśnicka and Głód, 2010, p. 318).

In the model of entrepreneurial cognition, Bird pointed out the role of interaction between entrepreneur and his environment that affects the individual cognitive process (Siu and Lo, 2013, pp. 147-173). A positive correlation between these variables can lead to an increase in the level of entrepreneurial intentions and increases the likelihood of realization of the process of establishing a business (Kraśnicka and Głód, 2010, p. 45). The author of this model pointed out the importance of attitudes in shaping entrepreneurial intentions and created a list of qualities and skills characteristic of entrepreneurial people. There are three levels (Piróg, 2015, p. 367):

- motives and characteristics (tolerance, control, willingness to take risks, high motivation to achieve goals),

- social roles and self-concept (appreciation of human relationships in a business context, attention to the high quality of 
work, assertiveness, confidence, attitude towards actions taken to overcome difficulties),

- knowledge and skills (basics of finance, accounting, management, principles of effective leadership, communication).

\section{Pilot Studies on the Entrepreneurial Intentions of Students}

The research was conducted in the first quarter of 2016 among 190 students of fourth semester of full-time undergraduate degree, majoring in Finance and Accounting at the Faculty of Management of Czestochowa University of Technology. As mentioned earlier, the aim of this research is to analyze entrepreneurial intentions of students in relation to issues such as: the perception of entrepreneurship and conditions for the initiation and conduct of business activity, and assessment of entrepreneurial potential. Research on entrepreneurial intentions of students is quantitative and was carried out using the method of audit questionnaire. The questionnaire contained questions about students' understanding of the concept of "entrepreneurship" and whether they perceive themselves as potential entrepreneurs, how they evaluate their options for action and conditions for self-employment. Students participating in classes of human resource management in financial institutions were asked to complete an anonymous survey within 45 minutes. After checking the correctness of filling, 158 questionnaires were selected for analysis. The aim of the author was to find answers to the following questions:

- whether students positively perceive and interpret entrepreneurship,

- whether students are willing to start their own businesses,

- what are the motivations associated with this enterprise,

- how students perceive the conditions for self-employment,

- what limitations make it difficult for them to start a business activity,

- how students assess their own abilities to be entrepreneurial.

The responses in Table 1 show that most people participating in the study were women $(64 \%)$, while $36 \%$ were men. The majority were people at the age of 21 $(47.2 \%)$ and $22(38.1 \%)$, followed by: the age of $20(6.5 \%)$, the age of $23(5.7 \%)$ and the age of $24(2.5 \%)$.

Table 1. Respondents divided by gender, age, place of residence

\begin{tabular}{|c|c|}
\hline Gender & Responses (\%) \\
\hline Female & 64.0 \\
\hline Male & 36.0 \\
\hline Age & Responses (\%) \\
\hline 20 & 6.5 \\
\hline 21 & 47.2 \\
\hline 22 & 38.1 \\
\hline 23 & 5.7 \\
\hline 24 & 2.5 \\
\hline Place of residence & Responses (\%) \\
\hline City & 61.7 \\
\hline Village & 38.3 \\
\hline
\end{tabular}

Source: own study based on research.

The importance of development of entrepreneurship for the growth of the economy should be noted; however, according to the ranking of the most respected professions in Poland, the entrepreneur is not in a top position (Jabłońska, 2016). Opening up to the idea of business requires shaping and developing the ability to release the potential of entrepreneurship from an early age. Starting a business is a prerequisite for economic development. It is a long process which can occur only when a person positively perceives entrepreneurship and has entrepreneurial intentions, which means considering the possibility of starting a business as a form of the realization of professional activity.

In the course of the research, students were asked to comment on the statements relating to the understanding of the term "entrepreneurship". The presented statements were based on a critical analysis proposed by T. Rantanen and T. Toikko (Rantanen and Toikko, 2013, pp. 7-25). The results concerning the perception of entrepreneurship are presented in Table 2.

The analysis of the results leads to the conclusion that $78.48 \%$ of students most often stated that entrepreneurs provide employment. Another statement to which students reacted positively $(67.08 \%)$ was 
Table 2. The perception of entrepreneurship by students

\begin{tabular}{|l|c|}
\hline \multicolumn{1}{|c|}{ Set of opinions on the understanding of entrepreneurship } & Responses (\%) \\
\hline Entrepreneurs are ideal citizens of the country & 0.00 \\
\hline Entrepreneurship is too often considered as a solution to many problems & 32.91 \\
\hline Entrepreneurs work hard and are responsible & 3.79 \\
\hline Entrepreneurs are swindlers and frauds & 1.89 \\
\hline Entrepreneurs are the key to success of a given society & 67.08 \\
\hline Entrepreneurship is overrated in our society & 0.63 \\
\hline Young people are too often encouraged to be entrepreneurs & 0.00 \\
\hline Too often entrepreneurship is said to be positive & 1.89 \\
\hline The work of entrepreneurs brings benefits to the whole society & 62.02 \\
\hline Entrepreneurs provide employment to people & 78.48 \\
\hline
\end{tabular}

Source: own study based on statements of T. Rantanen and T. Toikko from Gawel and Pietrzykowski (2015).

that entrepreneurs are the key to success of a given society. The third statement which students often chose $(62.02 \%)$ was that the work of entrepreneurs benefits the whole society. The statements with which the students did not agree should also be noted: entrepreneurs are ideal citizens of the country, young people are too often encouraged to be entrepreneurs.

Creation of a new company depends on the decision of a person who intends to deal with undertaking this project. It would seem that the transition to self-employment associated with the establishment of a company is an opportunity to avoid the situation of unemployment. However, observations show that few young people are choosing to take such a step and some start-ups fail. From the point of view of young people, the occurrence of a variety of obstacles that prevent the efficient running of their business may appear to discourage the start or continuation of their business activity. The key to understanding human actions is to learn of man's choices and beliefs that he associates with himself.

In order to learn about the opinions of students on their business plans, the author decided to investigate whether the respondents were interested in running their own business, and whether such an action would not involve taking excessive risks. From the responses to the question, it can be concluded that more than half of them $(61 \%)$ showed interest and willingness to run their own business, $20.5 \%$ of respondents answered "do not know", $18.5 \%$ of the students answered "no", and $7.0 \%$ answered "definitely not". The belief that running a business does not involve the necessity of incurring excessive risk was expressed by $69 \%$ of respondents. The remainder of the respondents $(31 \%)$ believes that the risk of running a business is associated with: the possibility of failure, incurring costs of starting a business, financial and legal responsibility for themselves and employees, the need for constant monitoring of market situation and the fight for customers.

A summary of global research conducted in the field of career psychology reveals that gender is an important factor in explaining significant differences in professional self-efficacy (Lent and Hackett, 1987, pp. 347-438). Numerous studies on entrepreneurship point to the fact that in most countries men show more interest and activity in starting new businesses than women (Alexander, 2013 p. 103). In order to verify whether these trends will persist, this study attempts to identify any differences between women and men in terms of motivation to start their own business and business management. The obtained results lead to the confirmation of the thesis included in the theoretical part of the study that gender affects the decisions of 
students regarding their business plans related to the desire of starting a business in the future. It turns out that women $(57.6 \%)$ significantly more often than men $(30 \%)$ declared that they were planning to take up such an activity. Research shows that students expressing the intention to undertake business ventures are guided by the following motives: financial independence - women $52.3 \%$, men $-40.6 \%$, self-employment - men $68.2 \%$, women $14 \%$, possibility of large profits - men $42.8 \%$, women $27.1 \%$, pursuing their own interests women $38.2 \%$, men $8.0 \%$, a desire to fulfill their dreams - women $30.3 \%$, men $16.4 \%$, a desire to be the boss and manage others men $12.2 \%$, women $8.0 \%$, flexible working hours - men $12.1 \%$, women $5.0 \%$, the ability to create and manage their own careers - women $28.2 \%$, men $12.9 \%$, a sense of ownership - men $10.3 \%$, women $4.0 \%$, appreciation among family and friends men $2.5 \%$, women $1.0 \%$, a desire to have power over others - men $0.5 \%$.

Research results prove that the representatives of both genders differ in terms of characteristics that foster and hinder entrepreneurial activities as well as selection of the profile of economic activity which they would prefer. The process of creating a company is not only the result of socio-economic conditions (related to the availability of resources, economic policy, economic traditions in the region), but largely of psychological characteristics of an entrepreneur. The starting point to become entrepreneur should be the recognition of one's own strengths and weaknesses, and only then the analysis of the market and industry in which one would like to be self-employed. The future success largely depends on the predisposition to conduct business independently. When choosing entrepreneurship as a career, the motivation to conduct business independently will not be enough. Being a good entrepreneur requires a predisposition, that is characteristics determining success in running a business. Entrepreneurship is related to an attitude focused on continued growth. Therefore, a man capable of being entrepreneurial can set ambitious goals and tasks the implementation of which leads to the achievement of ever improving results. One of the questions in the questionnaire prompted the students to reflect on themselves - "Do I have personality traits that shape a positive entrepreneurial attitude?". Respondents making a subjective assessment of their own attitudes towards entrepreneurship frequently mentioned: persistence in pursuing the objective - women $49.1 \%$, men $10.5 \%$; positive thinking women $42.5 \%$, men - no responses; setting ambitious objectives - women $30.2 \%$, men $9.3 \%$; ease in establishing contacts - men $24.5 \%$, women $13.4 \%$; ingenuity women $21.2 \%$, men $12.0 \%$; resourcefulness - women $9.6 \%$, men $5,2 \%$; responsibility - women $15.3 \%$, men $2.5 \%$; resistance to stress - women $12.3 \%$, men $2.5 \%$; dutifulness - women $14.2 \%$, men - no responses.

The aim of the research was also to compare opinions of representatives of both genders on the selection of profile of economic activity and to find out whether it is connected with their chosen field of study. The respondents participating in the survey were asked to indicate the type of business they would like to run. The students pointed to the following proposals: accounting office - women $69.7 \%$, men $3.2 \%$; financial activity - women $27.3 \%$, men $23.3 \%$; commercial activity(food shop, sports shop, auto parts store, clothing store) - men $42.7 \%$, women $7.3 \%$; catering - men $29.1 \%$, women - no responses; transport services - men $16.3 \%$, women no responses. University students demonstrated their knowledge on the possibilities of obtaining funds. The above responses indicate that in most cases, young people are planning activities related to their field of study, but some activities are not a good example of this.

From the point of view of the author of the survey, the time perspective in which potential entrepreneurs plan their future business is also interesting. More than half of respondents $(69 \%)$ claimed that they would start a business after graduation, whereas $3.8 \%$ of respondents were currently involved in running a family business. It turns out that $27 \%$ of respondents did not specify the date of setting up their own company. The analysis of data shows that students participating in the study demonstrate great interest in starting their own business. However, it should be noted that these are only declarations which do not need to be realized in a future perspective.

Starting a business does not guarantee success, one must have a business idea to 
enter the market in conditions of strong competition. The research shows that students draw inspiration from various sources, namely: observation of the market environment (57\%), knowledge derived from the Internet $(16.5 \%)$, talking to people $(9 \%)$, imagination $(6.5 \%)$, business experience of friends $(3.5 \%)$, accumulated knowledge based on experience - seasonal work $(6.8 \%)$. None of the respondents mentioned the experience which was a source of ideas for a business. This can be explained by the fact that, although they participate in student internships, they do not have sufficient professional experience to start their own business. This situation is a challenge for those responsible for planning and implementation of internships during which the students would be able to take the initiative and use the experience of business practitioners.

The study also included the opinions of students on the assessment of conditions of doing business. Also, the factors due to which young people do not want to start their own business were identified. Among the factors that are not conducive to the decision to start a business, the following external factors were highlighted: bureaucracy $(78 \%)$, too high requirements for starting a business (32.4\%), high taxes resulting from running a company $(30.4 \%)$, high competition $(12.1 \%)$. Some respondents $(10 \%)$ clearly indicated the lack of favorable market conditions for doing business. Internal barriers stemming from the perception of their own self included: lack of funds for starting a business (76.2\%), risk of failure $(17.1 \%)$, lack of sufficient knowledge and skills to run a company $(50.3 \%)$, lack of ideas for a business at present time (24\%). Therefore, universities should play a special role in this regard and take steps to stimulate the business creativity of students, especially as they are willing to explore such ideas.

Another question that was asked was inspired by the statement of P. Drucker that "entrepreneurship does not address the psychology and character traits of entrepreneurs, but their actions" (Drucker, 1992, p. 7). Therefore, the author decided to ask for opinions of students on whether the university where they study strives to involve them in the projects that present an opportunity to trigger entrepreneurship. The analysis of the collected empiri- cal material showed that the surveyed students do not participate in entrepreneurial initiatives, but they heard from other students that the university takes steps to create entrepreneurial attitudes. Among the most important entrepreneurial ventures initiated by the university were: Academic Career Office, student scientific clubs, international exchange, Days of Entrepreneurship.

\section{Conclusion}

Positive perception of entrepreneurship and entrepreneurial intentions is a key prerequisite affecting the success of the process of creating a new company. Entrepreneurial intentions precede behavior aimed at starting a business, and therefore the knowledge of them makes it possible to understand the nature of entrepreneurship. To show the mechanisms which cause the formation of entrepreneurial intentions, the most popular concepts were presented. They provide knowledge about the factors that increase the effectiveness of human entrepreneurial activities aimed at establishing and running a business.

The aim of this article was to address such issues as: the perception of entrepreneurship and conditions for the initiation and conduct of business activity and assessment of entrepreneurial potential. To achieve this objective, a pilot study using a survey was conducted among 158 students of the fourth semester of full-time undergraduate degree, majoring in Finance and Accounting at the Faculty of Management of Czestochowa University of Technology.

The research leads to the conclusion that the students of the second year of studies are interested in starting a business and express a desire to do so. It should be noted, however, that these are only declarations which do not need to be implemented in the future. The reasons for planning to achieve the said objective related to running a company are varied, but mostly dictated by the need to achieve financial independence and stability of employment. People participating in the study are negatively oriented to business conditions, which may be due to hasty declarations of the establishment of their own business activity. Students recognize the entrepreneurial potential in themselves, but they are aware of lack of competence necessary for effective imple- 
mentation of business ideas. Such findings obtained in the research lead to the conclusion that education for entrepreneurship leaves much to be desired due to missed opportunities with respect to equipping students with the latest knowledge and entrepreneurial attitudes. It is therefore necessary to make changes in the education system and curricula, which should be focused on activities related to self-employment and result in the adequate preparation of students for the labor market needs and running their own business. The main drawback of the work of an academic teacher is focusing attention primarily on preparing young people to seek a good job rather than developing skills useful to start and run their own business. Meanwhile, universities, as a tool to support the development of entrepreneurship, can play a significant role in shaping entrepreneurial behavior so that young people will be prepared to meet the demands of economic reality. Universities should equip young people with knowledge and entrepreneurial skills so that they can successfully use them in business. Studies should also provide knowledge about formal procedures related to the establishment of a company. In this context, of special importance will be: appropriate design of plans and curricula of studies, choice of teaching methods, implementation of apprenticeships, interaction with external environment. One of the recommended activities is that practical education should be based on cooperation between universities and companies, and the measurable effect would be an opportunity to engage students in the implementation of real business ventures.

\section{References}

Alexander, G. (2013). Women \& Entrepreneurship. Business People, May 2.

Bagheri, A. and Pihie, Z. (2014). The Factors Shaping Entrepreneurial Intentions. Cambridge Scholars Publishing.

Banerski, G., Gryzik, A., Matusiak, K., Mazewska M. and Stawasz, E. (2009). Przedsiębiorczość akademicka (rozwój firm spin-off, spin-out) - zapotrzebowanie na szkolenia slużace jej rozwojowi. Warszawa: Polska Agencja Rozwoju Przedsiębiorczości.

Brenes, E.R. and Haar, J. (2012). The Future of Entrepreneurship in Latin America. Palgrave Macmillan.
Buchta, K. and Jakubiak, M. (2014). Determinanty postaw przedsiębiorczych studentów jako element innowacyjności w procesie kształcenia. Zeszyty Naukowe WSEI, 9.

Butler, C. and Mador, M. (2015). Using entrepreneurship programmes to attract talent and to enhance educational impact. In: L. Foss and D. Gibson (eds.), The Entrepreneurial University: Context and Institutional Change. Routledge.

Canós-Darós, L. and Santandreu-Mascarell, C. (2011). Competence-Based Profile to Characterize Successful Entrepreneurs. In: S. Juana-Espinosa (ed.), Human Resource Management in the Digital Economy: Creating Synergy between Competency Models and Information. IGI Global.

Choinkowska, E. (2012). Budowanie postaw przedsiębiorczych w pracy pedagogicznej przez oddziaływanie psychologiczne. Przedsiębiorczość - Edukacja, 8.

Deszczyński, P. (2007). Rola uczelni wyższych w kształtowaniu postaw przedsiębiorczych z perspektywy absolwenta, menedżera i profesora. In: P. Wachowiak, M. Dabrowski and B. Majewski (eds.), Ksztattowanie postaw przedsiębiorczych a edukacja ekonomiczna. Akademia Ekonomiczna w Katowicach.

Drucker, P. (1992). Innowacja i przedsiębiorczość. Praktyka i zasady. Warszawa.

Elfving, J., Brännback, M. and Carsrud, A. (2009). Toward a Contextual Model of Entrepreneurial Intentions. In: A. Carsrud and M. Brännback (eds.), Understanding the Entrepreneurial Mind: Opening the Black Box. Springer Publishing House.

Gawel, A. and Pietrzykowski, M. (2015). Edukacja akademicka w postrzeganiu przedsiębiorczości i kształtowaniu intencji przedsiębiorczych. Problemy Zarzadzania, 13(1).

Jabłońska, G. (2016). W pogoni za prestiżem, czyli najbardziej poważane zawody w Polsce. Retrieved from www.rynekpracy.pl (09.07.2016).

Kilar, W. and Rachwał, R. (2014). Postrzeganie zakładania własnej działalności jako przejaw postawy przedsiębiorczej studentów kierunków nieekonomicznych. Horyzonty Wychowania, 28.

Kirchslaeger, P.G. (2014). Social entrepreneurial learning and human rights education. In: M.C. Pantea, R. Diroescu and M. Podlasek-Ziegler (eds.), Young people, entrepreneurship and non-formal learning: $A$ work in progress. SALTO-Youth Participation.

Kocoglu, M. and Hassan, M. (2013.) Assessing Entrepreneurial Intentions of University Students: A Comparative Study of Two Different Cultures: Turkey and Pakistani. European Journal of Business and Management, 5(13).

Kraśnicka, T. and Głód, G. (2010). Uwarunkowania intencji przedsiębiorczych studentów uczelni 
ekonomicznych Polski i Czech. Przedsiębiorczość Edukacja, 10

Krueger, N. (2002). Entrepreneurship: Critical Perspectives on Business and Management, Vol. 2. Taylor \& Francis.

Krueger, N. (1993). Impact of prior entrepreneurial exposure on perceptions of new venture feasibility and desirability. Entrepreneurship Theory and Practice, 18(1).

Kurczewska, A. (2010). Problemy pomiaru intencj przedsiębiorczych. E-mentor, 4.

Lent, R.W. and Hackett, G. (1987). Career SelfEfficacy: Empirical Status and Future Directions Journal of Vocational Behavior, 30.

Myjak, T. (2014). Kreowanie postaw przedsiębiorczych studentów w środowisku akademickim. Horyzonty Wychowania, 28.

OECD (2005). Higher Education Management and Policy, 17(3), Special Issue on Entrepreneurship. OECD Publishing.

Piróg, D. (2015). Kompetencje z zakresu przedsiębiorczości: rozważania teoretyczne i ich ilustracje w obszarze szkolnictwa wyższego. Przedsiębiorczośc - Edukacja, 11

Przedsiębiorczość w szkolnictwie wyższym szczególnie na studiach nieekonomicznych. Retrieved from file:///C:/Users/neonet/Downloads/entr_highed_pl.pdf (10.05.2016).

Rantanen, T. and Toikko, T. (2013). Social Values, Societal Entrepreneurship Attitudes and Entrepreneurial Intention of Young People In the Finnish Welfare State. Poznan University of Economics Review, 13(1).
Richert-Każmierska, A. (2011). Przedsiębiorczość jako przedmiot nauczania na wyższej uczelni wyzwania merytoryczne i metodyczne. E-mentor, 2.

Siu, W.-S. and Lo, E. S.-Ch. (2013). Cultural Contingency in the Cognitive Model of Entrepreneurship Intention. Entrepreneurship: Theory and Practice, 37(2).

Tomski, P. (2015). Intencje przedsiębiorcze a płeć $\mathrm{Ku}$ identyfikacji determinant. Przedsiębiorczośc i Zarzadzanie, XVI(7), part III, p. 83.

Tunkkari-Eskelinen, M. and Viitasaari, M. (2015). Towards Entrepreneurial Spirit at JAMK University of Applied Science; First Year Students' Views Towards Entrepreneurship. In: R.P. Dameri, R. Garelli and M. Resta (eds.), ECIE2015-10th European Conference on Innovation and Entrepreneurship. Academic Conferences and Publishing Limited.

Uygun, R. and Kasimoglu, M. (2013). The emergence of entrepreneurial intentions in indigenous entrepreneurs: The role of personal background on the antecedents of intentions. International Journal of Business and Management, 8(5).

Wach, K. and Wojciechowski, L. (2016). Entrepreneurial Intentions of Students in Poland in the View of Ajzen's Theory of Planned Behaviour. Entrepreneurial Business and Economics Review, 4(1).

Wach, K. (2015). Środowisko biznesu rodzinnego jako stymulanta intencji przedsiębiorczych młodzieży akademickiej. Przedsiębiorczość i Zarządzanie, $X V I(7)$, part III.

Zbierowski, P. (2014). Determinanty intencji przedsiębiorczej studentów - wyniki badań. Horyzonty Wychowania, 28. 